\title{
Financial Literacy Assessment on Tertiary Students in Sub-Saharan Africa: A Ghanaian Perspective
}

\author{
Beatrice Sarpong-Danquah (Corresponding author) \\ Department of Accounting and Finance, School of Business \\ Kwame Nkrumah University of Science and Technology (KNUST) \\ E-mail: bosei.knust.ksb@gmail.com
}

Prince Gyimah

Department of Accounting Studies Education

University of Education, Winneba - Kumasi Campus

Kwasi Poku

Department of Accounting and Finance, School of Business

Kwame Nkrumah University of Science and Technology (KNUST)

Brenda Osei-Poku

Finance Office, Unity Hall

Kwame Nkrumah University of Science and Technology (KNUST)

Received: March 31, 2018

Accepted: April 16, 2018

Published: May 8, 2018

doi:10.5296/ijafr.v8i2.12928

URL: https://doi.org/10.5296/ijafr.v8i2.12928

\begin{abstract}
The study assesses the financial literacy level among tertiary students in Sub-Saharan Africa country, Ghana. The study uses primary data through self-administered questionnaires, and employs purposive sampling to select four hundred and eighty (480) students across tertiary institutions in Ghana for data analysis. The study reaffirms that on the average, students lack
\end{abstract}


financial knowledge especially on insurance (mean $=40.54$ percent). However, students portray the highest level of financial literacy in savings and borrowing (mean $=52.88$ percent). Also, information technology positively influences 95 percent of student's financial literacy. We recommend that tertiary institutions should inculcate educational program on financial literacy to broaden understanding of financial issues among students. Policy makers should redesign curriculum to include financial literacy courses especially for non-business students. Finally, financial seminars and talks should be focused on teaching relevant financial concepts and the youth should be educated and encouraged to utilize digital or technological platforms to enable them gain more knowledge in finance.

Keywords: Financial literacy, Investment, Insurance, Savings and borrowing, Personal finance, Information Technology (IT), Tertiary students, Ghana

\section{Introduction}

Financial literacy is one of the key element of growth of individuals because they rely on it to make efficient and effective use of resources. Also, Financial literacy equips managers with the necessary skills to make sound and objective decisions on finance that can help sustain businesses. However, policy makers, financial regulatory authorities and associations of consumers are alarmed that individuals may lack the minimum knowledge of financial concepts required to make well-versed financial decisions. Research in some jurisdiction have shown that lack of financial literacy has led to high levels of personal and household debt (Lusardi \& Tufano, 2009; Stango \& Zinman, 2009), poor health (Joo \& Garman, 1998), inadequate retirement planning (Lusardi \& Mitchell, 2007), and inadequate stock market participation (Van et al., 2011). Thus, financial literacy has proven to be a very significant issue for discussion especially for students.

As students enter adulthood, a number of important financial decisions are to be taken such as moving away from home for which they might not be adequately ready. Uninformed financial decisions in the early stages of their lives as young adults may have damaging consequences on their lives (Lusardi et al., 2010). The absence of financial literacy appears to have an impact on students' tertiary performance. Students who are less financially literate suffer from financial distress. This goes a long way to affect their academic performance (Bongini et al., 2016). It is therefore essential for tertiary students to acquire basic financial knowledge either through more initiatives by government or other institutions.

Many researchers, prior to this study, have made supportive studies pertaining to the concept of financial literacy among tertiary students. For instance, Dergisi (2014) suggested that lack of financial literacy among university students threaten the security in the country. Also, students who are less financially literate are found to be less likely to plan for future uncertainties (Lusardi \& Mitchell, 2011). These studies have undoubtedly prompted individuals and nations the need to enlighten the awareness and involvement of students in financial literacy. This has indeed prompted the need to ascertain the level of financial literacy among tertiary students, including those in training colleges since prior researchers neglected those in training colleges in Ghana. This study is the first of its kind to assesses financial literacy among students in training colleges and universities in Sub-Saharan Africa 
country, Ghana. Specifically, the study assesses the difference in level of students' understanding and knowledge in personal financial management, savings, borrowing, investment and insurance. Also, the study examines the role of information technology in the improvement of financial knowledge among tertiary students.

Practically, the study is beneficial to employers that can help them know the level of financial knowledge of various sectors of tertiary institutions in Ghana. This can help employers to make effective training programs for new recruits as they could know the existing knowledge and areas that need further work in terms of financial literacy. Also, the study can aid whether to redesign curriculum and/or course development for various categories of tertiary institution in the country, based on the financial literacy needs of students. Policy makers, non-governmental organizations and organizers of various financial programs will be guided to focus their event topics on the actual financial needs of students rather than repeating same topic and same techniques each and every year. The findings of this study can help financial organizers redesign their events in order to make it more effective. Finally, the study contributes to knowledge due to extant literature in Ghana, and can serve as reference work on the contribution of financial literacy among tertiary students in emerging and developing economies.

The rest of the paper is structured as follows. The next section, section 2 reviews literature. Section 3 outlines methods used for the study. Section 4 presents and discusses results, and Section 5 gives the concluding remarks.

\section{Literature Review}

\subsection{Overview of Financial Literacy}

Financial literacy encompasses how global economic factors affect individuals' decisions (Worthington, 2006). A narrow view of financial literature explains that it focuses on just vital management tools such as budgeting, savings, investment and insurance (Natalie et al., 2011). It is further explained that the basic concepts required to make sensible savings and investment decisions are embedded in Financial Literacy (Lusardi \& Mitchell, 2007). Financial Literacy has been described as the capability of making informed judgements and to take effective decisions with connection to the utilization and management of money (Hung et al., 2009). Thus, financial literacy aims at measuring how individuals understand financial related situations and how they make informed financial decisions. Core concepts that may be identified as having permeated through these various definitions are personal finance, financial education, financial capability and financial distress. These concepts are explained below.

Personal finance generally involves evaluating one's current financial circumstances, forecasting short-term and long-term necessities and establishing a plan to satisfy those needs within one's financial restraints. Personal finance may capture activities such as paying for education, financing the purchase of durable goods, insurance activities, investment and retirement plans (Lusardi \& Mitchell, 2011). On the other hand, financial education refers to how money works in the world to enhance and influence future knowledge, attitude and 
behaviours (Grable \& Joo, 1998). Meanwhile, financial capability is the ability to portray rational judgment when faced with several financial choices (Lui et al., 2009). Finally, financial distress refers to stress emanating from personal, family or corporate financial circumstances (Joo \& Garman, 1998). However, this definition goes beyond just family, individual or corporate and tends to incorporate economic constraints (Delafrooz \& Paim, 2011). Financial literacy is said to have an inverse relationship with financial distress (Sabri \& Mohammed, 2011). Individuals or families who spend less than their income, pay for their expenses on time and avoid extravagant purchases tend to have less financial tension (Hibbert $\&$ Beutler, 2001).

\subsection{Financial Literacy Benefits}

Financial literacy is a vital life skill for all consumers (individuals, community and the economy). Financial literacy is made up of knowledge, complementary attitude and behaviours that enhance the implementation of this knowledge in the daily financial decision-making. It also helps consumers to make informed judgments and to make effective decisions regarding the use and management of money. Capuano and Ramsay (2011) provided some benefits associated with financial literacy to consumers (individuals), communities and the economy in a broader sense. Below are some of the benefits.

\subsubsection{Benefits to Consumers}

Financial education and skills equips both consumers and investors with the urge to acquire more information about the products and service rendered by financial institutions in a country. Financial literacy further promotes self-confidence, control and independence among consumers. When consumers feel they are taking hold of their finances, they are more expected to partake in the market (Knapp, 1991). Also, consumers possessing adequate level of knowledge in finance will save for the future, for retirement and also for uncertain future circumstances.

\subsubsection{Benefits to the Community}

Holzmann (2010) argues that financial literacy can increase financial inclusion in the society if the residents are financially literate. An in-depth knowledge and understanding in financial issues allows individuals the opportunity to make use of financial product and service for which financial illiterates may find difficult in using. It is revealed that financially knowledgeable people are able to appreciate and pass judgment on government policies (Jappelli, 2010). Moreover, financially literate individuals are also in the position to examine financial policies of governments and the activities of financial institutions in a particular country. Financial literacy enhances the understanding and acceptance of relevant political changes, such as health care or pension reforms.

\subsubsection{Benefits to the Financial System}

Studies have proven that individuals who plan for retirement actually save more for retirement and that the people who prepared adequately for retirement accumulate three times as much wealth as the people who did not (Lusardi \& Mitchell, 2011). Financially educated 


\section{MlMacrothink}

International Journal of Accounting and Financial Reporting ISSN 2162-3082 2018, Vol. 8, No. 2

customers are, most of the time, financially efficient. Such individuals encourage innovations among firms in the industry as they are always on the lookout for products of high quality and considerably low in prices. This attitude they exhibit forces the various firms who seek to survive in the market to give off their very best in the production of goods and provision of services. It is of the view that financial literacy strengthens market discipline, which is the collective consumer influence on financial institutional behaviour, making these institutions, more likely to operate in a safe, sound and efficient manner (Hall, 2008).

\subsection{Empirical Review}

Many researches show that financial literacy has a positive association with self-beneficial financial behaviour. Van et al. (2011) explored the relationship between financial complexity and wealth, by relying on specific criteria of financial literacy and the study discovered a strong relationship between financial literacy and savings and investment behaviour. Bernheim (1997) identified that in households, there is the absence of basic financial knowledge such as saving behaviours whereas in a more recent work, Bernheim and Garrett (2003) showed that respondents who are exposed to financial education in high school practise savings more than individuals who are not. According to Abel (2016), people with less financial knowledge are more prone to making bad decisions with regards to finance. Monticone (2010) argues that the less financially literates are heavily indebted and in the same direction whilst Lusardi and Mitchell (2014) also found out that people who were unable to calculate interest rates are more inclined to excessive borrowing and they tend to accumulate less wealth. Similarly, Schagen and Lines (1996) proposed that students, who were in higher level of education and were either residing independently or not living with their parents, are prone to debt mismanagement. Chen and Volpe (1998), in their study of college students in the United States, found out that they have a very low level of knowledge in insurance. Oppong-Boakye and Kansamba (2013) also concluded that when students are more knowledgeable and portray a more positive attitude towards money, they make enhanced decisions which enables them to judiciously use resources and improve their situations. Results from Dergisi (2014) reveal that university students in Konya, Turkey scored low marks in areas namely; savings and spending, risk and insurance, banking and insurance which suggested that students' financial literacy level was inadequate.

\section{Methods}

This study is designed to gather enough information with regards to the personal finance of students and hence we use explanatory, descriptive and exploratory research design. We adapted Mireku (2015) survey instrument to examine the knowledge of the concepts and principles in personal finance management, savings and borrowings, investment and insurance. Also, we use purposive sampling to select four hundred and eighty (480) students across public and technical universities and teacher-training colleges in Ghana. Our study purposely uses primary data through self-administered questionnaires. A key advantage of using this method is that, it assisted us in collecting data for each specific objective of the study. Data collected are edited, coded and analysed with the use of SPSS software. The study uses Cross Tabulation to analyse the differences in the level of understanding and 
knowledge displayed by tertiary students in personal financial management, savings and borrowing, investment and insurance. The responses from each participant were used to calculate the percentage of correct scores for each question, section and the entire survey.

Consistent with Chen and Volpe's $(1996,2002)$ criteria for the measurement of financial literacy which actually grouped the mean percentage of scores into three (3), namely; above $80 \%$ - relatively high, $60-79 \%$ - medium level of knowledge and below $60 \%$ - low level of knowledge, the mean percentage scores of the correct responses of this study were grouped into two (2), namely; (60 - 100\%) - high level of knowledge whilst $(0-59 \%)$ - low level of knowledge. Furthermore, a chi-square cross tabulation was used to establish an association between the financial literacy level of students and the frequency at which financial information is solicited from the various sources.

\section{Results and Discussion}

\subsection{Descriptive Statistics of the Respondents}

Table 1 provides a report on the descriptive statistics of the respondents in terms of age, gender, education and their personal monthly income. From Table 1, the result shows that majority of respondents representing $76.67 \%$ were between the ages of 20 and 25 years. The result therefore shows that the average age of students in higher learning institutions or tertiary institutions is 23 years, indicating that they are in their early adulthood. In terms of age, $60.21 \%$ of the respondents constitute males and $38.58 \%$ represent female respondents with $0.21 \%$ not responding to this question. This justifies the reality of gender imbalance in the tertiary institutions where male students are more than female students.

Also, Table 1 shows that $21.88 \%$ of the respondents offer business whilst $78.12 \%$ read non-business related programmes. Among the students reading non-business related programmes, $14.17 \%$ offer engineering courses, $5.83 \%$ read courses related to health sciences, $23.75 \%$ offer general and other sciences and $33.13 \%$ offer courses related to building, art and humanities. $1.25 \%$ did not respond to this question. Table 1 further shows that majority students used for the study are 1st year representing $32.71 \%$ as against 2 nd year being $22.50 \%$, 3rd year being $25.63 \%$ and 4th year representing the least proportion with $18.13 \%$. $1.04 \%$ of the respondents did not respond to this question. It is evident that majority of the respondents are 1 st year students, followed by $2 \mathrm{nd}$, 3rd and 4th year students. This may be due to the fact the first year level of tertiary education runs across tertiary institutions in Ghana. Lastly, in terms of income level, more than half of the respondents which is represented by $55.00 \%$ have their income below GHS400, with $18.54 \%$ within the ranges of GHS400 and GHS1, 499, 0.83\% within GHS1, 499 and GHS4,999, 0.42\% within GHS5,000 and GHS14,999 and 2.08\% receiving income above GHS15,000. However, 23.13\% of the sample did not respond to this question. As most of the respondents' income fall below GHS400, it could be assumed that the income of tertiary students consists mainly of monies from parents and relatives. 
Table 1. Demographic characteristics of respondent

\begin{tabular}{|c|c|c|}
\hline & $\begin{array}{l}\text { Total No. of } \\
\text { Participants }\end{array}$ & Percentage \\
\hline \multicolumn{3}{|l|}{ Age } \\
\hline Less than 20 & 90 & 18.75 \\
\hline 20 to 25 & 368 & 76.67 \\
\hline 26 to 30 & 15 & 3.13 \\
\hline 31 to 35 & 2 & 0.42 \\
\hline 36 and above & 3 & 0.63 \\
\hline No Response & 2 & 0.42 \\
\hline \multicolumn{3}{|l|}{ Gender } \\
\hline Male & 289 & 60.21 \\
\hline Female & 190 & 39.58 \\
\hline No Response & 1 & 0.21 \\
\hline \multicolumn{3}{|l|}{ Education } \\
\hline \multicolumn{3}{|l|}{ 1. Field Of Study } \\
\hline Business related & 105 & 21.88 \\
\hline Engineering & 68 & 14.17 \\
\hline Health Sciences & 28 & 5.83 \\
\hline General \& Other Sciences & 114 & 23.75 \\
\hline Building, Arts \& Humanities & 159 & 33.13 \\
\hline No Response & 6 & 1.25 \\
\hline \multicolumn{3}{|l|}{ 2. Year/Level } \\
\hline 1st Year & 157 & 32.71 \\
\hline 2nd Year & 108 & 22.5 \\
\hline 3rd Year & 123 & 25.63 \\
\hline 4th Year & 87 & 18.13 \\
\hline No Response & 5 & 1.04 \\
\hline \multicolumn{3}{|l|}{ Personal monthly income } \\
\hline Under GHS400 & 264 & 55.00 \\
\hline GHS400 - GHS1,499 & 89 & 18.54 \\
\hline GHS1,500 - GHS4,999 & 4 & 0.83 \\
\hline GHS5,000-GHS14,999 & 2 & 0.42 \\
\hline Above GHS 15,000 & 10 & 2.08 \\
\hline No response & 111 & 23.13 \\
\hline
\end{tabular}

4.2 Pattern of Responses to Financial Literacy Questions

\subsubsection{Personal Financial Management}

From Table 2, 43.75\% answered the personal financial planning question correctly, 55.42\% provided a wrong answer and $0.83 \%$ did not respond. This implies that only about $44 \%$ of the 
respondents knew the importance of personal financial planning. Only $45.63 \%$ got the question on personal budget correct, $53.96 \%$ got it wrong and $0.42 \%$ did not respond. Student were expected to have much knowledge in personal budget since cost of living on campus has become higher but this did not turn out to be so.

The correct and wrong responses as well as the no response to the question, 'personal financial planning is influenced by the following except', were $24.58 \%, 75 \%$ and $0.42 \%$ respectively. However, the test question that expected students to indicate the wisest personal financial planning strategy, produced a very reassuring result compared to the other questions in this section. About $91 \%$ of the respondents answered the question correctly, $8.33 \%$ got it wrong and $0.42 \%$ did not respond to it. This shows that students actually know how to rationally align their spending strategy towards a very good financial planning.

\subsubsection{Savings and Borrowing}

This examines students' knowledge in savings and borrowing and five questions were asked to aid in measuring the level of financial literacy. The initial question sought to find out if the respondents knew the method of saving that produced the highest return. From Table 2, $38.33 \%$ got it correct, $60.21 \%$ got it wrong and $1.46 \%$ did not respond. This proves that although students know about the various avenues to save, most of them do not consider the one that produces the highest return, probably because they do not care about the return but just the principal.

The next question tested students on how to calculate interest on savings and $91.88 \%$ got it correct, $7.5 \%$ got it wrong and $0.63 \%$ did not respond. This shows that students have vast knowledge on basic interest. The third question, which sought to explore if students knew reasonable criteria to be considered before saving in a financial institution, produced an encouraging result: $63.33 \%$ got the question correct, $35.83 \%$ got it wrong and $0.83 \%$ did not answer. This shows that students are fairly meticulous in choosing an avenue for saving.

In the 'saving for emergencies' question, 50\% answered it correctly, $48.33 \%$ got it wrong and $1.67 \%$ did not respond. This is not that bad as it could be concluded that students rightly know where to save in order to get their money back during emergencies. The final question sought to find out if students know certain distinctive characteristics of fixed deposit accounts but the result showed that students do not have much knowledge about fixed deposit accounts. This is evidenced by $20.83 \%$ of the respondents answering the question correctly, $77.08 \%$ answering the question wrongly whilst $2.08 \%$ providing no response.

\subsubsection{Investment}

Nine questions were asked in all, with the first question setting a positive example by producing encouraging results. $66.25 \%$ of the respondents were able to correctly identify what investment is, among various options while $32.71 \%$ could not. $1.04 \%$ did not respond to this question. Averagely, it shows that students have a fair knowledge about investment. However, the respondents fall short in identifying what a short term investment is. From Table 2, it is shown that $34.79 \%$ got this question correct, $63.33 \%$ got it wrong whilst $1.88 \%$ did not answer the question. Also, only $15.83 \%$ know that if interest rates rise, bond price 
will decrease while $81.46 \%$ do not. $2.71 \%$ gave no response. This was expected from the students since bond is not an investment package that is frequently practised in Ghana.

Nevertheless, the fourth question, which sought to find out if students knew about the relationship between risk and return of investment, turned out to be positive. $65.83 \%$ of the respondents correctly identified that an investment with a high return is likely to be of high risk while $32.29 \%$ think otherwise. $1.88 \%$ did not give any response. This proves that however; students fairly know that a high investment is most likely going to produce a high return.

In terms of diversification of risks, it was evident that students were not aware that risk is reduced when spread among more than one portfolios. This is shown on Table 2, as $48.54 \%$ were able to tell that one could reduce his/her risk by diversifying his/her investment while $49.38 \%$ think otherwise and a no response of $2.08 \%$. In the sixth question, $50.83 \%$ correctly chose Treasury bill as the safest investment as against $47.71 \%$ who got that answer wrong. $1.46 \%$ did not answer this question. This was expected from students as Treasury bill seems to be a financial package in which individuals in Ghana are actively involved.

Only $27.29 \%$ were able to indicate correctly that an individual tends to earn more when the interest is compounded more frequently while $68.96 \%$ wrongly opted for other options. $3.75 \%$ provided no response to this question. This means most students do not know that one earns more when his/her interest is compounded more frequently. Only $33.75 \%$ and $24.17 \%$ were able to identify the riskiest investment and the least risky investment option respectively by calculating the return on each investment while $64.38 \%$ and $73.54 \%$ got it wrong. $1.88 \%$ and $2.29 \%$ respectively provided no response. This shows that though more than fifty percent of the respondents knew about the inverse relationship that exists between risk and return, a higher percentage of the respondents couldn't find the risk that is associated with the various investment packages by calculating the returns.

\subsubsection{Insurance}

This region, which sought to explore the level of students' knowledge in insurance, contained five questions. In determining why an insurance is purchased, $29.79 \%$ of the respondents answered the first question correctly. $67.71 \%$ got it wrong and $2.50 \%$ did not answer at all. This clearly shows that students do not know why exactly insurance is purchased. In the second question, a fair number of respondents failed to recognise that all the insurance packages mentioned were examples of insurance packages, with $41.67 \%$ of the respondents getting it correct. $55.42 \%$ got it wrong and $2.92 \%$ did not attempt this question.

Respondents also proved to have a fair knowledge in what a premium is, as a concept in insurance. This is shown by $50.63 \%$ scoring that question correctly. Just about $46 \%$ got it wrong and $3.13 \%$ of the respondents did not answer the question. However, it was discouraging to find out that students had poor knowledge in determining what an annuity is. $24.17 \%$ of the respondents got the question related to annuity correct whilst a majority, $73.13 \%$, got it wrong. $2.71 \%$ did not respond to this question. 
Interestingly, students proved to have a substantial knowledge in knowing who a beneficiary is. This is shown on Table 2 as 56.46\% answered the question correctly and 41.04\%. $2.5 \%$ did not answer this question. Table 2, below, presents the mean percentages of the correct responses of the respondents from the three institutions. This is to aid in arriving at the differences in the knowledge and understanding of the various components of financial literacy, namely; personal financial management, savings and borrowing, investment and insurance.

Table 2. Pattern of responses to financial literacy questions

\begin{tabular}{|c|c|c|c|}
\hline & Correct & Wrong & No Response \\
\hline \multicolumn{4}{|l|}{ Personal Financial Management } \\
\hline Personal financial planning & $43.75 \%$ & $55.42 \%$ & $0.83 \%$ \\
\hline Personal budget & $45.63 \%$ & $53.96 \%$ & $0.42 \%$ \\
\hline Personal financial planning factors & $24.58 \%$ & $75.00 \%$ & $0.42 \%$ \\
\hline Spending Strategy & $91.25 \%$ & $8.33 \%$ & $0.42 \%$ \\
\hline Mean & $51.30 \%$ & & \\
\hline \multicolumn{4}{|l|}{ Savings \& Borrowing } \\
\hline Savings for highest return & $38.33 \%$ & $60.21 \%$ & $1.46 \%$ \\
\hline Interest & $91.88 \%$ & $7.50 \%$ & $0.63 \%$ \\
\hline Consideration before saving & $63.33 \%$ & $35.83 \%$ & $0.83 \%$ \\
\hline Savings for emergencies & $50.00 \%$ & $48.33 \%$ & $1.67 \%$ \\
\hline Fixed deposit & $20.83 \%$ & $77.08 \%$ & $2.08 \%$ \\
\hline Mean & $52.88 \%$ & & \\
\hline \multicolumn{4}{|l|}{ Investment } \\
\hline Investment & $66.25 \%$ & $32.71 \%$ & $1.04 \%$ \\
\hline Short term investment & $34.79 \%$ & $63.33 \%$ & $1.88 \%$ \\
\hline Increase in interest rate of bond & $15.83 \%$ & $81.46 \%$ & $2.71 \%$ \\
\hline High return investment & $65.83 \%$ & $32.29 \%$ & $1.88 \%$ \\
\hline Diversification & $48.54 \%$ & $49.38 \%$ & $2.08 \%$ \\
\hline Safest investment & $50.83 \%$ & $47.71 \%$ & $1.46 \%$ \\
\hline Compound interest & $27.29 \%$ & $68.96 \%$ & $3.75 \%$ \\
\hline Most riskiest investment & $33.75 \%$ & $64.38 \%$ & $1.88 \%$ \\
\hline Least riskiest investment & $24.17 \%$ & $73.54 \%$ & $2.29 \%$ \\
\hline Mean & $40.81 \%$ & & \\
\hline \multicolumn{4}{|l|}{ Insurance } \\
\hline Insurance & $29.79 \%$ & $67.71 \%$ & $2.50 \%$ \\
\hline Insurance packages & $41.67 \%$ & $55.42 \%$ & $2.92 \%$ \\
\hline Premium & $50.63 \%$ & $46.25 \%$ & $3.13 \%$ \\
\hline Annuity & $24.17 \%$ & $73.13 \%$ & $2.71 \%$ \\
\hline Beneficiary & $56.46 \%$ & $41.04 \%$ & $2.50 \%$ \\
\hline Mean & $40.54 \%$ & & \\
\hline
\end{tabular}




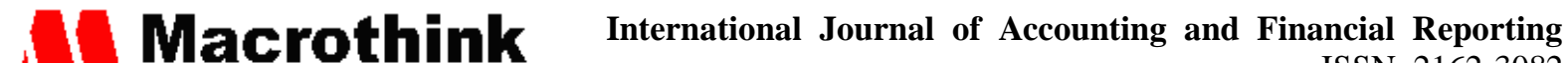 ISSN 2162-3082 2018, Vol. 8, No. 2}

\subsection{Financial Literacy Measurement Discussion}

Table 3 shows the summary of the overall mean percentage of the correct responses of the total sample. This is represented by a mean of 46.38\%. Applying Chen and Volpe's (1996, 2002) criteria for the measurement of financial literacy which actually grouped the mean percentage of scores into three; above $80 \%$ - relatively high, $60-79 \%$ - medium level of knowledge and below $60 \%$ - low level of knowledge. It can be concluded that students from tertiary institutions in Ghana have a low level of financial literacy. However, the overall mean of correct responses of the various components of financial literacy - personal financial management, savings and borrowing, investment and insurance - could further be broken down as $51.3 \%, 52.88 \%, 40.81 \%$ and $40.54 \%$ respectively.

It is observed that tertiary students have an adequately fair knowledge in savings and borrowing (52.88\%) while their knowledge in personal financial management, investment and insurance is relatively lower. This is consistent with the findings of Dergisi (2014) who concluded that University students in Turkey have the highest average score of $75 \%$ in savings and spending while Mireku (2015) also reported similar situation among university students in Ghana with an average score of $60.9 \%$ in savings and borrowing.

It was also observed that tertiary students portray the lowest level of knowledge in insurance with a mean percentage score of 40.54 . This conclusion is affirmed by the study of Chen and Volpe (1998), who also made the assertion that the level of knowledge in insurance was quite low (a mean percentage score of less than 65\%) among US college students. More precisely, there is also similar assertions in Mireku (2015) which concluded that students of Ghanaian universities have the lowest level of knowledge in insurance with a mean percentage score of 40.6 .

With respect to investment, results suggest that respondents portray a low level of knowledge, with a mean score of $40.81 \%$. This affirms the findings of Degrisi (2014) and Mireku (2015) who also reported a low level of knowledge in investment as being part of financial literacy. It can therefore be concluded that students in tertiary institutions have a low level of financial literacy and such level of illiteracy is fairly distributed among the three categories of institutions. Nevertheless, university students prove to be more financially literate than technical university students who are also more financially literate than students from training colleges.

Table 3. Measure of financial literacy

\begin{tabular}{lc}
\hline Financial Literacy Variables & Percentage \\
\hline Personal Financial Management & 51.30 \\
Savings and Borrowing & 52.88 \\
Investment & 40.81 \\
Insurance & 40.54 \\
Overall Financial Literacy & 46.38 \\
\hline
\end{tabular}




\subsection{Effectiveness of the Various Sources of Financial Information}

This section establishes the relationship between the scores of respondents in the test of their financial literacy level and the frequency at which they obtain finance-related information from some selected sources. The test grade represents the percentage score of the respondents as per the answers provided under each component of financial literacy. They are put into two (2) categories; Pass and Fail. The Pass grade is the percentage score of the respondents whose scores range from $60 \%$ to $100 \%$, while the Fail grade represents scores below $60 \%$. The frequency grade, on the other hand, represents the rate at which respondents receive finance-related information from some selected sources. The frequency grade is further broken into frequently and rarely, where frequently depicts regular and repeated rate of receiving information and rarely revealing an occasional and infrequent rate of receiving finance-related information. Table 4 presents the results.

From Table 4, 401 of the 480 respondents frequently received information from the various avenues and the remaining 79 respondents hardly have access to information from the sources. Out of the 401 respondents who accessed information frequently from the named sources, $74.06 \%$ failed and only $25.94 \%$ passed. For the 79 respondents who rarely contacted the avenues for information, $91.14 \%$ failed and $8.86 \%$ passed the financial literacy test.

The chi square test conducted, shows that the probability of the chi-square test statistic is at 0.001 which is less than the probability of the alpha level of significance, 0.05 . Therefore, the null relationship hypothesis can be rejected with certainty and rather, the conclusion could be that there exists a significant relationship between the sources of financial information and their financial literacy level. The relationship established however seems to be negative, that is, the individuals who contact the avenues on a frequent basis, failed the financial literacy test.

Moreover, out of the number who failed, greater proportion assessed information frequently from the listed sources. This can be attributed either to the fact that the students do not understand the information as presented by the sources or the sources do not communicate the information to their recipients efficiently. This renders these sources of financial information ineffective in their role to improve students' knowledge in finance.

Table 4. Frequency grade (Test Grade Cross Tabulation)

\begin{tabular}{|c|c|c|c|c|c|}
\hline & & & \multicolumn{3}{|c|}{ Test Grade } \\
\hline \multirow[b]{3}{*}{ Frequency } & \multirow{3}{*}{ Frequently } & & Fail & Pass & Total \\
\hline & & Count & 297 & 104 & 401 \\
\hline & & $\%$ & $74.06 \%$ & $25.94 \%$ & $100.00 \%$ \\
\hline \multirow[t]{4}{*}{ Grade } & \multirow{2}{*}{ Rarely } & Count & 72 & 7 & 79 \\
\hline & & $\%$ & $91.14 \%$ & $8.86 \%$ & $100.00 \%$ \\
\hline & \multirow[t]{2}{*}{ Total } & Count & 369 & 111 & 480 \\
\hline & & $\%$ & $76.88 \%$ & $23.12 \%$ & $100.00 \%$ \\
\hline
\end{tabular}

Chi-Square $=10.823, \mathrm{P}<0.001$ 


\subsection{The Role of IT in Improving Financial Literacy Level Among Tertiary Students}

This section seeks to identify the role of information technology (IT) in providing financial information to students at the tertiary level using a 5-point Likert scale that ranges from strongly agree to strongly disagree. Our results show that $95 \%$ of the respondent attested to the fact that IT could go a long way in improving their financial literacy level. Table 5 shows the result. From Table 5, 67.5\% do not know about the existences of any app/software, a website or any online course that gives financial information, $10 \%$ knew of some of the technological instruments but had never used them and only $22.5 \%$ actually took advantage of the existing software applications.

Probing further into what could be some of the reasons why the respondents do not use I.T. as a tool to better their literacy level in finance, most of them claimed it never occurred to them to use I.T. as a financial tool. Others also responded that they do not think there is the need for such information now since they do not have 'enough money' but will do so at the right time. Some of the respondents also blame school authorities for establishing such tight schedules in school (as per their academic time tables and other social activities) making it difficult to use these apps and software packages mostly in the form of games. Notwithstanding all these, more than $80 \%$ of the participants who actually use these tools disclosed, in a discussion with them, on how some of these apps work and how helpful and educative they are and that they are willing to use the available apps/software packages and require more information be given to them concerning where one could locate such apps.

Table 5. Usage of technological instruments

\begin{tabular}{lcccc}
\hline & \multicolumn{3}{c}{ Knowledge } \\
\hline & & & Yes & No \\
& Yes & $\%$ & $22.50 \%$ & $0.00 \%$ \\
Usage & & Count & 9 & 0 \\
& No & $\%$ & $10.00 \%$ & $67.50 \%$ \\
& & Count & 4 & 27 \\
\hline
\end{tabular}

\section{Concluding Remarks}

The study assesses the level of financial knowledge of students in tertiary institutions in Sub-Saharan Africa country, Ghana. Findings of the study suggest that tertiary students have less than average knowledge in finance. They seem to have more knowledge in savings and borrowings than in personal financial management followed by investment and the least, knowledge in insurance. Only $25.94 \%$ represents students who frequently receive financial information. This suggests that either the information provided through the various mediums failed to address basic finance issues or is not presented in a manner that students could understand. Either way, financial information provided from various sources proves to be ineffective in terms of financial literacy among students.

Since the world has experienced significant technological changes in various aspects of life, one would expect most students not to just know but use financial applications and/or software but that does not seem to be the case in Ghana, as most of the students do not know 


\section{Mll Macrothink}

International Journal of Accounting and Financial Reporting

ISSN 2162-3082

2018, Vol. 8, No. 2

there exists software and applications that could help improve their financial literacy. Out of the little that do know, $69.23 \%$ use at least one of these applications or software while the rest do not.

We recommend that there is the need for educational program on financial literacy to broaden understanding of financial issues among tertiary students. Policy makers should redesign curriculum to include financial literacy courses especially for non-business students. Finally, financial seminars and talks should be focused on teaching relevant financial concepts and the youth should be educated and encouraged to utilize digital/technological platforms to enable them gain more knowledge in finance.

One limitation of the present study is that, the study looks into various institutions in Ghana, however various institutions have different level in financial literacy. Thus, future studies should conduct among the various institutions in order to explore the causes of these underlying differences in the financial literacy level. Researchers should also replicate the study in different countries in order to validate the empirical results of the study. Finally, since the study concludes that the various sources of financial information were ineffective to improve financial literacy level, further studies should delve into why these sources are unable to improve the level of financial literacy and how this situation can be amended.

\section{References}

Abel, S. (2016). Cost of financial illiteracy. Bostwana. Retrieved from www.herald.co.zw/

Bernheim, B. D., \& Garrett, D. M. (2003). The effects of financial education in the workplace: evidence from a survey of households. Journal of public Economics, 87(7-8), 1487-1519. https://doi.org/10.1016/S0047-2727(01)00184-0

Bongini, P., Trivellato, P., \& Zenga, M. (2016). Financial literacy and Undergraduates. Journal of Financial Managment Markets and Institutions, 4(1), 23-42. https://doi.org/10.12831/83857

Capuano, A., \& Ramsay, I. (2011). What Causes Suboptimal Financial Behaviour? An Exploration of Financial Literacy, Social Influences and Behavioural Economics. $U$ of Melbourne Legal Studies Research Paper No. 540. http://dx.doi.org/10.2139/ssrn.1793502

Chen, H., \& Volpe, R. P. (1998). An analysis of personal financial literacy among college students. Financial Services Review, 7(2), 107-128. https://doi.org/10.1016/S1057-0810(99)80006-7

Chen, H., \& Volpe, R. P. (2002). Gender differences in personal financial literacy among college students. Financial Services Review, 11(3), 289-307.

Delafrooz, N., \& Paim, L. H. (2011). Determinants of financial wellness. African Journal of Business Management, 5(24), 10092.

Dergisi, M. V. F. (2014). A survey of financial literacy among univeristy students. The Journal of Accounting and Finance, 2, 220. 


\section{Mll Macrothink}

International Journal of Accounting and Financial Reporting

ISSN 2162-3082

Grable, J. E., \& Joo, S. (1998). Does financial education affect knowldge, attitudes and behavior? An empirircal evidence. Personal FInances and Worker Productivity, 2(2), 213-230.

Hall, K. (2008). The importance of financial literacy. Reserve Bank of Australia: In Speeches.

Hibbert, J. R., \& Beutler, I. F. (2001). The effects of financial behaviors on the quality of family life: Evidence from adolescent perceptions. In Proceedings of the Association for Financial Counselling and Planning Education, Symposium conducted at the 19th Annual Association for Financial Counselling and Planning Education Conference, Orlando, FL.

Holzmann, R. (2010). Bringing Financial Literacy and Eduation to Low and Middle Income Countries. Malaysia: Pension Research Council Working Paper.

Hung, A. A., Parker, A. M., \& Yoong, J. (2009). Defining and Measuring Financial Literacy. New Jersey: RAND Corporation.

Jappelli, T. (2010). Economic Literacy: An international comparision. The Economic Journal, 120(548), 429-451. https://doi.org/10.1111/j.1468-0297.2010.02397.x

Joo, S.-h., \& Garman, T. (1998). Personal financial wellness may be the missing factor in understanding and reducing worker absenteeism. Personal Finances and Worker Productivity, 2(2), 172-182.

Knapp, J. P. (1991). The benefits of consumer education: A survey report [Brochure]. Michigan Consumer Education Centre.

Lui, K., McIntyre, H., Fields, M., \& Summerville, D. (2009). Personal Financial Literacy in New Hampshire. New Hampshire: PRS Policy Brief 0809.

Lusardi, A., \& Mitchell, O. S. (2007). Financial Literacy and Retirement Planning. Michigan: New Evidence from the Rand American Life Panel.

Lusardi, A., \& Mitchell, O. S. (2011). Financial literacy and planning: Implications for retirement welbeing. Cambridge: National Bureau of Economic Research.

Lusardi, A., \& Mitchell, O. S. (2014). The economic importance of financial literacy: Theory and evidence. Journal of Economic Literature, 52(1), 5-44. https://doi.org/10.1257/jel.52.1.5

Lusardi, A., \& Tufano, P. (2009). Debt Literacy, Financial Experiences and Overindebtedness. Cambridge: National Bureau of Economic Research.

Lusardi, A., Mitchell, O. S., \& Curto, V. (2010). Financial literacy among the young. Journal of consumer affairs, 44(2), 358-380. https://doi.org/10.1111/j.1745-6606.2010.01173.x

Mireku, K. (2015). Financial literacy among university students: evidence from Ghana. Kumasi: (Doctoral Dissertation, Department of Accounting and Finance, Kwame Nkrumah University of Science and Technology).

Monticone, C. (2010). How much does wealth matter in the acquisition of financial literacy?. Journal of Consumer Affairs, 44(2), 403-422. 


\section{MInstitute ${ }^{\text {Mink }}$}

International Journal of Accounting and Financial Reporting

ISSN 2162-3082

Natalie, G., Cameron, N., \& Chrisann, P. (2011). Framework for assessing financial literacy and superannuation investment choice decisions. Austrailian Accounting Business and Finance Journal, 5(2), 3.

Oppong- Boakye, P. K., \& Kasanba, R. (2013). An assessment of financial literacy levels among undergraduate business students in Ghana. Research Journal of Finance and Accounting, 4(8), 36-49.

Sabri, M. (2011). Pathways to Financial Success: Determinants of Financial Literacy and Financial Well-being among Young Adults. Iowa: (Doctoral Dissertation, Iowa State University).

Schagens, S., \& Lines, A. (1996). Financial Literacy in adult life: a report to the Natwest Group Charitable Trust. London: NFER.

Stango, V., \& Zinman, J. (2009). What Do Customers Really Pay on Thier Checking and Credit Card Accounts? Explicit, Implicit, and Avoidable Costs. The American Review, 99(2), 424-429. https://doi.org/10.1257/aer.99.2.424

Van Rooij, M., Lusardi, A., \& Alessie, R. (2011). Financial literacy and stock market participation. Journal of Financial Economics, 101(2), 449-472. https://doi.org/10.1016/j.jfineco.2011.03.006

Worthington, A. C. (2013). Financial literacy and financial literacy programmes in Australia. $\begin{array}{llll}\text { Journal of Financial } & \text { Services }\end{array}$ https://doi.org/10.1057/fsm.2013.18

\section{Copyright Disclaimer}

Copyright for this article is retained by the author(s), with first publication rights granted to the journal.

This is an open-access article distributed under the terms and conditions of the Creative Commons Attribution license (http://creativecommons.org/licenses/by/4.0/) 